\title{
Penerapan Metode Ceramah Dalam Meningkatkan Pemahaman Berbagai Sistem Dalam Kehidupan Manusia Pada Siswa SMP Negeri 2 Siak Hulu
}

\author{
ASMEL WINDRA \\ Dinas Pendidikan Kabupaten Kampar \\ SMP Negeri 2 Siak Hulu \\ E-mail : asmelwindra@gmail.com
}

\begin{abstract}
The system in human life is very complex, it requires understanding for students to be able to understand well in learning. Teachers as educators provide a variety of actions taken especially in the application of methods that seek to improve understanding. The lecture method is indeed considered a method that has been used for a long time. But until now it is still considered effective. Through the classroom action research method for research by applying the lecture method and analyzed by qualitative analysis based on the results, it shows that the application of the lecture method can increase the understanding of Siak Hulu Middle School 2 students regarding various systems in human life.
\end{abstract}

Keywords: Lecture Method, Life System

Peningkatan kualitas pendidikan harus dipenuhi melalui peningkatan kualitas dan kesejahteraan pendidik dan tenaga kependidikan lainnya.Pembaharuan kurikulum yang sesuai dengan perkembangan ilmu pengetahuan dan teknologi tanpa mengesampingkan nilainilai luhur sopan santun dan etika serta didukung penyediaan sarana dan prasarana yang memadai, karena pendidikan yang dilaksanakan sedini mungkin dan berlangsung seumur hidup menjadi tanggung jawab keluarga, sekolah, masyarakat dan pemerintah.

Tugas utama guru adalah mengelola proses belajar dan mengajar, sehingga terjadi interaksi aktif antara guru dengan siswa, dan siswa dengan siswa. Interaksi tersebut sudah pasti akan mengoptimalkan pencapaian tujuan yang dirumuskan Tujuan utama pembelajaran Ilmu Pengetahuan Alam (IPA) adalah agar siswa memahami konsep-konsep IPA secara sederhana dan mampumenggunakan metode ilmiah, bersikap ilmiah untuk memecahkan masalah-masalah yang dihadapi dengan lebih menyadari kebesaran dan kekuasaan pencipta alam (Depdikbud, 1997:2).

Pembelajaran IPAmemiliki fungsi yang fundamental dalam menimbulkan serta mengembangkan kemampuan berpikir kritis, kreatif dan inovatif. Agar tujuan tersebut dapat tercapai, maka IPA perlu diajarkan dengan cara yang tepat dan dapat melibatkan siswa secara aktif yaitu melalui proses dan sikap ilmiah. Mutu pembelajaran IPA perlu ditingkatkan secara berkelanjutan untuk mengimbangi perkembangan teknologi.Sehingga seorang guru harus dapat mengetahui karakteristik peserta didik terlebih dahulu.

Peningkatan kualitas pendidikan dapat dicapai apabila kegiatan pelayanan pada proses belajar mengajar di kelas dapat dikelola dan berlangsung dengan baik berdaya guna berhasil guna. Hal tersebut dapat dilaksanakan apabila ditunjang dengan adanya rencana, pelaksanaan, pengawasan dan penilaian dari pimpinan atau kepala sekolah lembaga pendidikan tersebut. Selain itu juga upaya peningkatan kemampuan dan kualitas guru sangat diperlukan seperti dengan memberikan dorongan atau motivasi serta memberikan perhatian yang lebih. Kemudian kelengkapan sarana dan prasarana dalam menunjang proses belajar mengajar juga ikut berkontribusi serta yang tak kalah penting adalah 
kepemimpinan kepala sekolah dalam mengelola sekolahnya.

Sebab merekalah sebagai pelaksana terdepan atau ujung tombak terlaksananya kegiatan belajar mengajar di sekolah. Berhasil atau tidaknya upaya peningkatan mutu pendidikan banyak ditentukan oleh kompetensi yang ada pada mereka tersebut dalam mengembangkan tugas pokok seharihari. Guru dengan jenis pekerjaan ini tidak dapat dilaksanakan kebanyakan orang di luar pendidikan. Keahlian khusus yang dimaksud adalah upaya penanganan yang lebih spesifik dan perlunya kecermatan yang mendalam. Hal ini dapat dilihat dari beberapa tugas guru diantaranya mendidik, mengajar dan melatih. Mendidik berarti meneruskan dan mengembangkan nilainilai hidup, kemudian mengajar berarti meneruskan dan mengembangkan ilmu pengetahuan dan teknologi, selanjutnya melatih berarti mengembangkan keterampilan melalui minat, bakat dan kreativitas. Namun pada kenyataannya masih saja ada berbagai kendala, kelemahan dan kekurangan guru didalam menjalankan tugas sebagai profesi.

Seorang guru menyadari bahwa titik pusat tujuan sekolah menyediakan program pendidikan yang direncanakan untuk memenuhi kebutuhan hal-hal yang berkaitan dengan pendidikan, pribadi dan kebutuhan kemasyarakatan serta kepentingan individu para siswa. Siswa merupakan klien utama yang harus dilayani, oleh sebab itu siswa harus dilibatkan secara aktif dan tepat, tidak hanya dalam proses belajar mengajar melainkan juga di dalam kegiatan sekolah.

Perubahan yang makin meningkat mengakui bahwa guru secara individual harus mendapatkan perhatian. Terdapat banyak hal yang perlu mendapatkan perhatian dari seorang guru, seperti masalah kompetensinya. Berbicara masalah kompetensi guru saat ini menjadi hal yang menarik. Banyak persoalan tentang kompetensiguru dalam memberikan pelayanan pendidikan kepada peserta didik, seperti persoalan dunia kerja guru yang memberikan pengajaran, guru dengan pimpinannya, kemudian persoalan guru dengan muridnya, guru dengan lingkungannya juga menjadi masalah tersendiri yang ikut menentukan mutu pendidikan.

Guru yang mengajar di sekolah menengah pertama memerlukan kesiapan yang ekstra, karena pada fase umur remaja (tingkat SMP) siswa baru mengalami fase perubahan. Sekolah Menengah Pertama (SMP) adalah salah satu lembaga pendidikan yang bertugas untuk menyelenggarakan pendidikan formal di tingkat menengah. Sekolah menengah diselenggarakan untuk melanjutkan ke jenjang berikutnya dan menyiapkan peserta didik menjadi anggota masyarakat yang memiliki kemampuan mengadakan interaksi dengan lingkungan sosial, budaya dan alam sekitar serta dapat mengembangkan kemampuan dan keterampilan lebih lanjut kedalam dunia kerja.

Lokasi penelitian ini dilakukan di SMP Negeri 2 Siak Hulu, berdasarkan pengamatan di lapangan pada pelajaran IPA ditemukan fenomena pencapaian hasil belajar siswa kurang dari KKM atau dikatakan belum berhasil. Diketahui bahwa berdasarkan pre tes yang dilakukan pada mata pelajaran IPA khususnya siswa kelas IX mengenai peranan usaha, gaya dan energy dari 23 siswa terdapat 20 orang atau $87 \%$ siswanya tidak tuntas atau lebih kecil hasil belajarnya dibandingkan dengan KKM yang ditetapkan yakni 82 .

Selain itu juga masalah yang dihadapi siswa adalah, siswa kurang memahami akan makna pelajaran peranan usaha, gaya dan energi dalam kehidupan sehari-hari dan juga kurang mampu menghafal rumus-rumus yang ada pada peranan usaha, gaya dan energi dalam kehidupan sehari-hari, kesulitan menghafal dan memahami pelajaran menjadi kendala tersendiri bagi siswa dalam mengikuti pelajaran IPA tersebut dan siswa cenderung bingung dalam mengikuti pelajaran yang diberikan. 
Kemudian sikap siswa dalam belajar cenderung pasif dalam mengikuti pelajaran, dimana pada saat guru meminta siswa bertanya atau menanggapi pelajaran yang diberikan siswa cenderung diam saja dan juga pada saat guru bertanya kepada siswa, siswa malahan ketakutan menjawabnya. Selain itu juga siswa kurang semangat mengikuti materi pelajaran yang diberikan dan berusaha untuk mencari alasan untuk tidak mengikutinya.

Istilah metode berasal dari dua kata yaitu meta dan hodos. Meta berarti "Melalui" dan hodos berarti "Cara". dengan demikian, metode dapat berarti jalan atau cara yang harus dilalui untuk mencapai sebuah tujuan. Selain itu, ada juga yang mengatakan bahwa Meted adalah suatu sarana untuk menemukan, menguji dan menyusun data yang diperlukan bagi pengembangan disiplin tersebut.

Ceramah merupakan salah satu metode mengajar yang paling banyak digunakan dalam proses belajar mengajar. Metode ceramah ini dilakukan dengan cara menyampaikan materi pelajaran kepada peserta didik secara langsung atau dengan cara lisan. Penggunaan metode ini sifatnya sangat praktis dan efisien bagi pemberian pengajaran yang bahannya banyak dan mempunyai banyak peserta didik. Metode ceramah merupakan cara mengajar yang paling tradisional dan telah lama dijalankan dalam sejarah pendidikan, oleh karena itu metode ini boleh dikatakan sebagai metode pengajaran tradisional karena sejak dulu metode ini digunakan sebagai alat komunikasi guru dalam menyampaikan materi pelajaran. Metode ini sejak dulu sudah digunakan dalam mengembangkan dan mendakwakan agama Islam baik Nabi Muhammad saw maupun para Sahabatsahabatnya. .

Untuk mendapatkan gambaran yang jelas tentang pengertian metode ceramah, dapat kita lihat beberapa defenisi yang dikemukakan oleh para ahli yaitu:

Menurut Suryono (1992) Metode ceramah adalah Penuturan atau penjelasan guru secara lisan, di mana dalam pelaksanaanya guru dapat menggunakan alat bantu mengajar untuk memperjelas uraian yang disampaikan kepada muridmuridnya.

Menurut Roestiyah N.K (2001) Metode ceramah adalah Suatu cara mengajar yang digunakan untuk menyampaikan keterangan atau informasi atau uraian tentang suatu pokok persoalan serta masalah secara lisan. Menurut Team Didaktik Metodik (1995) "Metode ceramah adalah Penerangan dan penuturan secara lisan oleh guru terhadap kelas".

Slameto (1991: 84) menyebutkan bahwa: "mengajar adalah kegiatan mengorganisasi yang bertujuan untuk membantu dan menggairahkan siswa belajar". Mengajar dapat diartikan sebagai proses menyampaikan pengetahuan dan kecakapan tertentu kepada anak didik. Yang lain menyebutkan bahwa mengajar adalah mengorganisasi lingkungan secara kondusif sehingga dapat menciptakan siswa yang melakukan proses belajar secara efektif.

Mengajar merupakan aktifitas yang dilakukan oleh guru dalam melakukan interaksi dengan siswa. Aktivitas guru dilakukan secara bertahap, diawali dengan menyusun perencanaan secara menyeluruh tentang segala sesuatu yang akan dilakukan pada saat terjadi interaksi dengan siswa dan pemanfaatan sumber-sumber yang ada untuk mendukung selama kegiatan yaitu melakukan evaluasi, menganalisis dan melakukan pencatatan-pencatratan terhadap sesuatu yang terjadi pada saat interaksi berlangsung.

Pada saat terjadi interaksi dengan siswa, maka guru memilih dan melakukan dengan cara-cara tertentu agar kegiatan interaksi dengan siswa dapat berjalan dengan kondusif sehingga tujuan yang diharapkan dapat tercapai. Cara-cara yang dilakukan oleh guru dalam melakukan interaksi dengan siswa disebut metode mengajar. 
Metode mengajar memiliki peranan yang sangat penting dalam proses belajar mengajar. Soetomo (1993: 144) menyebutkan: "metode mengajar sebagai suatu alat untuk mencapai tujuan pengajaran yang ingin dicapai, sehingga semakin baik penggunaan metode mengajar semakin berhasillah pencapaian tujuan. Penggunaan metode mengajar secara tepat dapat menumbuhkan minat siswa untuk dapat mengikuti kegiatan belajar mengajar dengan baik, sehingga kreatifitas anak akan muncul dan berkembang dengan baik pula. Namun sebaliknya, jika penggunaan metode mengajar ini kurang tepat, maka akan menjadi tidak bermakna bahkan dapat mematikan kreatifitas siswa.

\section{METODE}

Metode yang digunakan dalam penelitian ini adalah metode penelitian tindakan kelas merupakan: (1) penelitian partisipatoris yang menekankan pada tindakan dan refleksi berdasarkan pertimbangan rasional dan logis untuk melakukan perbaikan terhadap suatu kondisi nyata; (2) memperdalam pemahaman terhadap tindakan yang dilakukan dan (3) memperbaiki situasi dan kondisi kelas pembelajaran secara praktis", Pendekatan yang digunakan dalam penelitian tindakan ini ialah pendekatan kualitatif.

Teknik pengumpulan data dari penelitian tindakan sekolah ini adalah melalui data kualitatif yang diperoleh dari observasi, pengamatan, maupun wawancara. Analisa data yang digunakan dalam penelitian ini adalah analisa data kualitatif yang bersumber dari data primer maupun empiris.

\section{HASIL}

Penelitian tindakan kelas (PTK) ini dilaksanakan dalam tiga siklus. Hal ini dikarenakan keterbatasan waktu yang tersedia, serta dengan tiga siklus sudah penulis anggap cukup untuk peningkatan pemahaman siswa.

Rekapitulasi tingkat pemahaman siswa terhadap sistem kehidupan dilihat dari kemampuan siswa menjawab dan menyampaikan pertanyaan dapat dilihat jawaban pemahaman siswa dalam memahami sistem kehidupan melalui ceramah di kelas XII mata pelajaran pendidikan agama islam pada siklus 1 . Dari hasil rekapitulasi data tersebut dapat diketahui pada siklus pertama pemahaman siswa pada sistem kehidupan dinyatakan kurang, dengan persentasi ketuntasan sebesar $28.6 \%$ dan yang tidak tuntas sebesar $71.4 \%$.

Setelah selesai satu siklus maka diadakan refleksi mengenai kelemahan atau kekurangan dari pelaksanaan tindakan pada siklus pertama. Refleksi dilaksanakan bersama-sama berkolaborator untuk menentukan tindakan perbaikan pada siklus berikutnya. Dari hasil refleksi dapat diambil suatu kesimpulan bahwa perlu penerapan metode ceramah kepada siswa dalam sistem kehidupan perlu mendapatkan penguatan pada siklus berikutnya.

Siklus 2 terdiri beberapa tahapan yang sama seperti siklus 1, yaitu: 1) Perencanaan; 2) Pelaksanaan; 3) Pengamatan dan 4) Refleksi. Dari hasil rekapitulasi data tersebut dapat diketahui pada siklus kedua pemahaman siswa pada sistem kehidupan dinyatakan cukup, dengan persentasi ketuntasan sebesar $38.1 \%$ dan yang tidak tuntas sebesar $61.9 \%$.

Rekapitulasi tingkat pemahaman siswa terhadap sistem kehidupan dilihat dari kemampuan siswa menjawab dan menyampaikan pertanyaan dapat dilihat jawaban pemahaman siswa dalam memahami sistem kehidupan melalui ceramah data tersebut dapat diketahui pada siklus ketiga pemahaman siswa pada sistem kehidupan dinyatakan paham, yang tuntas sebesar $76.2 \%$ dan yang belum tuntas $23.8 \%$.

\section{PEMBAHASAN}

Dari hasil observasi dan data yang diperoleh, peneliti mengambil kesimpulan bahwa tindakan yang dilaksanakan pada siklus ketiga dinyatakan lebih baik bila dibandingkan dengan siklus pertama dan 
kedua.

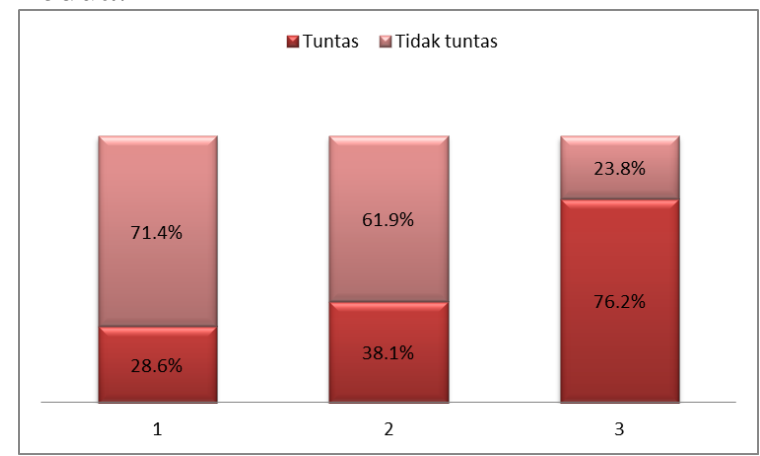

\section{SIMPULAN}

Dari uraian di atas, maka dapat disimpulkan bahwa melalui metode ceramah, maka pemahaman siswa akan sistem kehidupan semakin nyata, semakin memahami siswa maka akan mudah siswa menerapkkannya dalam kehidupan seharihari. Data yang diperoleh menunjukkan bahwa setelah dilakukan penerapan metode mengajar ceramah, maka terbukti adanya pengaruh yang ke arah yang positif dalam meningkatkan pemahaman siswa.

\section{DAFTAR RUJUKAN}

Depdiknas, 2003, Undang-Undang No. 20 Tahun 2003 Tentang Sistem Pendidikan Nasional, Depdiknas.

Slameto, 2003, Belajar dan factor-faktor yang mempengaruhinya, Jakarta: Rineka Cipta.

Slameto, 1991, Proses belajar mengajar dalam sistem kredit semester (SKS) Jakarta: Bumi Aksara

Mulyasa E, 2005, Menjadi guru professional, menciptakan pembelajaran kreatif dan menyenangkan, Bandung. PT. Remaja Rosdakarya Offset.

Soetomo, 1993, Dasar-dasar interaksi belajar mengajar, Usaha nasional, Surabaya
Suryono, dkk, Teknik Belajar Mengajar Dalam CBSA, (Cet. I; Jakarta: Rineka Cipta, 1992), h. 99

Roestiyah N.K, Strategi Belajar Mengajar, (Jakarta: Rineka Cipta, 2001), h. 137

Team Didaktik Metodik, Pengantar Didaktik Metodik Kurikulum PBM, (Cet. V; Jakarta: PT. Grafindo persada, 1995), h. 39 